УДК 616.441-006.6-08

DOI 10.11603/2414-4533.2016.3.6791

(c) Н. Я. КОБРИНСЬКА

ДУ “Інститут ендокринології та обміну речовин ім. В. П. Комісаренка НАМН України”, м. Київ

\title{
Особливості лікування мультифокальної високодиференційованої тиреоїдної карциноми
}

\author{
N. YA. KOBRYNSKA \\ V. Komisarenko Institute of Endocrinology and Metabolism, Kyiv
}

\section{FEATURES TREATMENT OF THE MULTIFOCAL HIGHLY DIFFERENTIATED THYROID CARCINOMA}

\begin{abstract}
Здійснено порівняльний аналіз моно- та мультифокальних високодиференційованих тиреоїдних карцином. Всього проаналізовано 2211 випадків монофокальних та 693 випадки монофокальних уражень. У результаті проведеного аналізу встановлено, що у хворих на мультифокальну карциному порівняно з хворими на монофокальну карциному операційне лікування частіше проводили в 1999-2008 рр., у них частіше застосовували тиреоїдектомію з дисекцією і значно рідше - інші операції, у тому числі й кінцеву тиреоїдектомію, у цих пацієнтів частіше здійснювали повторні операції, відмічали частіше трикратне і більше застосування радіойоду, серед них реєстрували більше невилікуваних хворих, за ними здійснювали триваліше спостереження після операції.

A comparative analysis of mono- and multifocal highly differentiated thyroid carcinomas was conducted. There were analyzed 2211 cases and 693 cases of monofocal lesions. The analysis found that patients with multifocal carcinoma compared with patients with monofocal carcinoma surgery was often conducted in 1999-2008 years, they had increasingly applied thyroidectomy with dissection and much less other operations, including the final thyroidectomy in them often carried out repeated operations was noted they often use more than threefold and radioiodine, including registered patients no longer cured by them carried a longer follow-up after surgery.
\end{abstract}

Постановка проблеми і аналіз останніх досліджень та публікацій. Аналіз результатів лікування багатофокусного раку щитоподібної залози (Щ3) за даними літератури показав, що ця проблема привертає увагу багатьох дослідників у галузі ендокринної хірургії [1-12] тощо. Щодо лікування мультифокальної папілярної карциноми щитоподібної залози, яке висвітлено в цій літературі, можна використати такі тактики:

- радикальне видалення залози;

- видалення залози, доповнене лімфодисекцією;

- видалення залози з подальшою абляцією залишкової тиреоїдної тканини радіоактивним йодом;

- операційне втручання, проте із збереженням органа;

- профілактичну центральну дисекцію.

Звичайно, що кожен із цих методів лікування зумовлений особливостями клініко-патологічного перебігу мультифокальної високодиференційованої карциноми і вони мають як прихильників, так і супротивників.

Експерти Консенсусу з мультифокальної високодиференційованої тиреоїдної карциноми [13] щодо тактики лікування багатофокусного раку щитоподібної залози висловили таку думку.
Щодо тиреоїдектомії при мультифокальній високодиференційованій тиреоїдній карциномі, то рекомендації, основані на ретроспективних дослідженнях, пропонують тотальну тиреоїдектомію здійснювати у пацієнтів з мультифокальною папілярною тиреоїдною карциномою, оскільки вона зменшує ризик місцевого рецидиву, який суттєво вищий після виконання операції на ЩЗ резекційного характеру.

Узгоджена думка експертів про профілактичну шийну дисекцію при мультифокальній високодиференційованій тиреоїдній карциномі така: двостороння профілактична центральна шийна дисекція повинна виконуватись у пацієнтів із загальним діаметром пухлини більше 1см або у випадках зі значною кількістю вогнищ раку, оскільки частота субклінічних метастазів у центральних лімфатичних вузлах вища при мультифокальній високодиференційованій тиреоїдній карциномі і може ефективно лікуватися дисекцією вузлів без збільшення ризику ускладнень.

Проведення остаточної тиреоїдектомії, на думку експертів, виправдано при встановленні діагнозу мультифокальної високодиференційованої тиреоїдної карциноми після первинної операції ре- 
зекційного характеру для забезпечення повного видалення мультицентричного захворювання i/або 3 метою подальшого проведення радіойодтерапії.

Радіойодтерапію проводять пацієнтам із високодиференційованим раком ЩЗ після тотальної тиреоїдектомії з метою абляції остаточної тканини ЩЗ і досягнення нульових рівнів тиреоглобуліну в сиворотці, для опромінення кожного неопластичного вогнища і зниження ризику рецидиву, для проведення сканування всього тіла радіойодом при підозрі на персистенцію хвороби. На думку експертів, абляція йодом після первинної операції повинна розглядатись у пацієнтів з мультифокальною високодиференційованою тиреоїдною карциномою, коли за допомогою персоналізованої оцінки ідентифікується підвищений ризик рецидиву або ризик метастатичного розповсюдження.

Оцінюючи характер спостереження при мультифокальній високодиференційованій тиреоїдній карциномі, експерти вважають, що оптимальне спостереження пацієнтів 3 мультифокальною високодиференційованою тиреоїдною карциномою ще остаточно не визначено, головним чином, через нестачу даних, оскільки немає достатньої кількості досліджень з цього приводу.

Мета роботи: характеристика методів лікування хворих на мультифокальну високодифенційовану карциному щитоподібної залози порівняно $з$ хворими на монофокальну карциному.

Матеріали і методи. Дослідження проведено на основі матеріалів, взятих з історії хвороби стаціонарного хворого та із протоколу операцій на 2904 хворих, які лікувались в ДУ “Інститут ендокринології та обміну речовин ім. В. П. Комісаренка НАМН України” в 1999-2015 рр. 3 них 2211 хворих із монофокальною карциномою, 693 - 3 мультифокальною.

Порівнювали показники розподілу хворих на моно- та мультифокальну карциному за тими чи іншими методами лікування. Достовірність показників між порівнюваними показниками визначали методом хі-квадрат $\left(\chi^{2}\right)$.
Результати досліджень та їх обговорення. Встановлено, що спостережені нами хворі обох порівнюваних груп операційне лікування в основному отримували в 2009-2014 pp. і пізніше: хвоpi 3 монофокальною карциномою - 81,7 \% осіб, а хворі з мультифокальною карциномою - 62,2 \% осіб. Водночас до 2009 р. оперували більше хворих із мультифокальною карциномою - 35,8 \% осіб проти 18,3 \% осіб з монофокальною карциномою. Різниця ця суттєва $(\mathrm{p}<0,01)$.

Які види операційного втручання на щитоподібній залозі отримали порівнювані групи хворих, показано в таблиці 1. Зазначимо, що в цій таблиці показано лише три види операцій, а саме: тиреоїдектомію, тиреоїдектомію з дисекцією та інші види, до яких увійшли органозберігаючі операції (ПГ+Р), (ЛАГТЕ+(ЛГ+Р)+(ПРГТЕ)+ОКТЕ). OKTЕ з цієї групи винесено ще й окремо.

Наведені в таблиці 1 дані свідчать про те, що “чиста” тиреоїдектомія була здійснена у більшості хворих обох порівнюваних груп: у 59,7 \% осіб з монофокальною карциномою і в 59,7 \% осіб, хворих на мультифокальну карциному. Водночас тиреоїдектомію з дисекцією значно частіше проводили у хворих на мультифокальну карциному: у 34,1 проти 21,2 \% осіб, хворих на монофокальну карциному. Інші види операцій на ЩЗ, у тому числі й кінцеву тиреоїдектомію, значно частіше здійснювали у хворих на монофокальну карциному. Ця різниця статистично аргументована з надійністю в 99 \% і більше.

Хірургічне лікування карцином щитоподібної залози в загальному випадку передбачає тиреоїдектомію за більшістю публікацій, рекомендацій, консенсусів. Тим більше, слід очікувати, що наявність багатофокусного росту буде вимагати повного видалення щитоподібної залози. Про таку тактику, як стратегічний напрямок, свідчать дані про виконані операції у хворих досліджених груп (табл. 1). Тиреоїдектомію (з чи без лімфодисекції) було виконано 1787 пацієнтам із монофокальною карциномою, що склало 80,9 \% та 649 пацієнтам з мультифокальною карциномою, що склало 93,8 \%. Кінцеву тиреоїдектомію також достовірно

Таблиця 1. Розподіл хворих на моно- та мультифокальну високодиференційовану тиреоїдну карциному за видами операційного втручання

\begin{tabular}{|c|c|c|c|c|c|c|}
\hline \multirow{3}{*}{ Вид операції } & \multicolumn{4}{|c|}{ ККарцинома } & \multirow{3}{*}{$\chi^{2}$} & \multirow{3}{*}{$\mathrm{p}$} \\
\hline & \multicolumn{2}{|c|}{ монофокальна } & \multicolumn{2}{|c|}{ мультифокальна } & & \\
\hline & абс. & $\%$ & абс. & $\%$ & & \\
\hline Тиреоїдектомія & 1318 & 59,7 & 413 & 59,7 & \multirow{4}{*}{91,73} & \multirow{4}{*}{$<0,01$} \\
\hline Тиреоїдектомія з дисекцією & 469 & 21,2 & 236 & 34,1 & & \\
\hline Інші види & 422 & 19,1 & 43 & 6,2 & & \\
\hline 3 них: кінцева тиреоїдектомія (OKTE) & 157 & 7,1 & 20 & 2,9 & & \\
\hline Усього & 2209 & 100,0 & 692 & 100,0 & - & - \\
\hline
\end{tabular}


частіше виконували хворим 3 мультифокальною карциномою (2,9 проти 7,1% відповідно). При цьому тиреоїдектомію з дисекцією достовірно частіше було виконано в групі мультифокальних тиреоїдних крацином (34,1 проти 21,2 \%), p<0,01. Ці дані узгоджуються з результатами більшості інших досліджень [5, 10, 14 ]. При цьому деякі рекомендації дозволяють виконувати навіть органозберігаючі операції за умови розміру пухлини не більше 1 см $[7,15,16]$. Хоча частіше лунає думка щодо обов’язкової профілактичної серединної лімфодисекції у всіх хворих із мультифокальною тиреоїдною карциномою $[11,12,17]$. Стосовно кількості перенесених операцій (табл. 1) з достовірністю $\mathrm{p}<0,05$ можна зазначити, що більше їх було виконано у хворих із мультифокальною тиреоїдною карциномою (6,5 проти 4,6 \% відповідно).

Як відомо, при лікуванні раку щитоподібної залози застосовують радіойод. Те, як часто застосовується радіойод у спостережуваних нами хворих, показано в таблиці 2.

3 наведених у таблиці 2 даних слідує, що радіойод не застосовували більш ніж у третини хворих порівнюваних груп, по одному разу радіойод застосовували у половини обох груп, по 2 рази радіойод застосовували, наприклад, в однакової кількості хворих цих груп, а от по три рази і більше радіойод частіше застосовували у хворих на мультифокальну карциному, що підтверджується статистично на рівні 90-95 \% ймовірності.
У таблиці 3 представлено дані про кількість років спостереження за хворими спостережуваних груп.

Порівняння моно- та мультифокальних тиреоїдних карцином за кількістю років спостереження (табл. 3), безумовно, не $є$ безпосередньою характеристикою кожної з цих груп. Але опосередковано достовірно більша кількість хворих, що спостерігається при мультифокальних карциномах протягом 3-х років і більше (17,7 проти 11,5 \%), свідчить про більшу “прискіпливість” як лікарів, так і хворих з цією формою захворювання. В цілому ці дані доводять, що більше половини пацієнтів (52,6 \%) спостерігали не менше 2 повних років (тобто до 3). А понад 100 хворих у нашому дослідженні мали термін спостереження більше 6 повних років, що склало 10 \%. Треба зауважити, що аналіз проведено на великій кількості хворих переважно за даними електронного реєстру, тобто без виклику тисяч пацієнтів на обов'язковий огляд. Враховуючи наявні в Україні економічні та соціальні складнощі, більшість пацієнтів після декількох років благополучного спостереження перестають приїжджати до інститутської клініки на черговий огляд. 3 огляду на це, кількість пацієнтів, за якими отримано результати, залишається, на наш погляд, суттєвою та презентабельною.

Зрозуміло, що головним параметром всього лікування карцином взагалі, зокрема тиреоїдних i мультифокальних, $є$ наявність та тривалість після-

Таблиця 2. Розподіл хворих на моно- та мультифокальну високодиференційовану тиреоїдну карциному за кількістю курсів радіойоду

\begin{tabular}{|c|c|c|c|c|c|c|}
\hline \multirow{3}{*}{$\begin{array}{c}\text { Курсів } \\
\text { радіойоду }\end{array}$} & \multicolumn{4}{|c|}{ Карцинома } & \multirow{3}{*}{$\chi^{2}$} & \multirow{3}{*}{$\mathrm{p}$} \\
\hline & \multicolumn{2}{|c|}{ монофокальна } & \multicolumn{2}{|c|}{ мультифокальна } & & \\
\hline & абс. & $\%$ & абс. & $\%$ & & \\
\hline 0 & 845 & 38,2 & 274 & 39,6 & \multirow{5}{*}{8,67} & \multirow{5}{*}{$0,05<\mathrm{p}<0,01$} \\
\hline 1 & 1120 & 50,7 & 332 & 47,9 & & \\
\hline 2 & 177 & 8,0 & 50 & 7,2 & & \\
\hline $3-5$ & 58 & 2,6 & 30 & 4,3 & & \\
\hline 6 і більше & 11 & 0,5 & 7 & 1,0 & & \\
\hline Усього & 2211 & 100,0 & 693 & 100,0 & - & - \\
\hline
\end{tabular}

Таблиця 3. Розподіл хворих на моно- та мультифокальну високодиференційовану тиреоїдну карциному за кількістю років спостереження

\begin{tabular}{|c|c|c|c|c|c|c|}
\hline \multirow{3}{*}{$\begin{array}{c}\text { Років } \\
\text { спостереження }\end{array}$} & \multicolumn{4}{|c|}{ Карцинома } & \multirow{3}{*}{$\chi^{2}$} & \multirow{3}{*}{$\mathrm{p}$} \\
\hline & \multicolumn{2}{|c|}{ монофокальна } & \multicolumn{2}{|c|}{ мультифокальна } & & \\
\hline & абс. & $\%$ & абс. & $\%$ & & \\
\hline 0 & 631 & 28,5 & 188 & 27,1 & \multirow{5}{*}{20,82} & \multirow{5}{*}{$<0,01$} \\
\hline 1 & 548 & 24,8 & 141 & 20,3 & & \\
\hline 2 & 778 & 35,2 & 242 & 34,9 & & \\
\hline $3-5$ & 175 & 7,9 & 78 & 11,3 & & \\
\hline 6 і більше & 79 & 3,6 & 44 & 6,4 & & \\
\hline Усього & 2211 & 100,0 & 693 & 100,0 & - & - \\
\hline
\end{tabular}


операційного безрецидивного спостереження. При цьому головним фактором, що свідчить про наявність такого благополучного терміну, є відсутність, за даними УЗД, будь-яких додаткових утворів [6]. Безумовно, сьогодні також широко використовується визначення тиреоглобуліну та антитіл до нього в сироватці крові, але на початку спостереження за обраною групою хворих тиреоглобулін лише з'являвся та не був обов'язковим методом, тим паче обов'язковим для занесення в електронний реєстр. Тоді більше уваги приділяли діагностичному скануванню. Час минув, але подібні ретроспективні обстеження вже не можуть відновити втрачений час та дані. Тому ми зосередились на визначенні у вигляді показника наявності рецидиву за даними УзД. Треба зазначити, що наші спеціалісти УзД набули високої кваліфікації завдяки сумнозвісній Чорнобильській трагедії. У сукупності з сучасними апаратами УЗД ми маємо змогу стверджувати, що отримані при УЗД дані у більшості відбивають реальну картину з оцінкою післяопераційного спостереження. Крім того, відомо, що більшість тиреоїдних карцином передусім метастазує в регіонарні колектори лімфовідтоку, спостереження за якими $€$ найбільш ефективним саме при УЗД.

На закінчення в таблиці 4 наводимо дані про результати лікування спостережуваних нами обох груп хворих.

Таблиця 4. Розподіл хворих на моно- та мультифокальну високодиференційовану тиреоїдну карциному за вилікуваністю по УЗД

\begin{tabular}{|c|c|c|c|c|c|c|}
\hline \multirow{3}{*}{ Результати УЗД } & \multicolumn{4}{|c|}{ Карцинома } & \multirow{3}{*}{$\chi^{2}$} & \multirow{3}{*}{$\mathrm{p}$} \\
\hline & \multicolumn{2}{|c|}{ монофокальна } & \multicolumn{2}{|c|}{ мультифокальна } & & \\
\hline & абс. & $\%$ & абс. & $\%$ & & \\
\hline Вилікувались & 2051 & 92,8 & 629 & 90,8 & \multirow{2}{*}{29,64} & \multirow{2}{*}{$<0,01$} \\
\hline Не вилікувались (є метастази) & 160 & 7,2 & 64 & 9,2 & & \\
\hline Усього & 2211 & 100,0 & 693 & 100,0 & - & - \\
\hline
\end{tabular}

У таблиці 4 наведено результати щодо відсутності (вилікувались) чи наявності (не вилікувались) додаткових утворів у ділянці шиї за УЗД (ложа щитоподібної залози та регіонарних колекторів лімфовідтоку). За отриманими даними, понад 90 \% пацієнтів на час завершення дослідження вже були вилікувані. Але серед тих, хто мав пролонгацію захворювання (додаткові утвори в ділянці шиї), достовірно частіше виявляли хворих з мультифокальною карциномою (9,2 проти 7,2 \%). Ці дані ще раз підтвердили той висновок, що наявність мультифокального ураження є фактором ризику, який призводить до більш агресивного перебігу тиреоїдної карциноми.

\section{СПИСОК ЛІТЕРАТУРИ}

1. Эпителиально-мезенхимальная трансформация папиллярных микрокарцином щитовидной железы / И. И. Яковцова, И. В. Ивахно, О. В. Долгая [и др.] // ScienceRise. - C. 85-91.

2. Трошин В. П. Характеристика тиреоидных раков в регионе, пострадавшим от аварии на Чернобыльской АЭС (19862006 гг.) : автореф. дисс. на соискание учен. степени докт. мед. наук : 14.00.15 / В. П. Трошин. - СПб., 2009. - 40 с.

3. Коваленко А. Є. Особливості клініки та хірургічного лікування хворих на рак щитовидної залози після аварії на Чорнобильській AEC : автореф. дис. на здобуття наук. ступеня докт. мед. наук : спец.14.01.14 / А. Є. Коваленко. - К., 2003. -28 c.

4. Діагностика, лікування, спостереження та реабілітація хворих на рак щитовидної залози : метод. рек. - Львів, 2006. $-41 \mathrm{c}$.

5. Prognosis of multifocal papillary thyroid carcinoma: clinical study / Kuo Sheng-Fong, Lin Shu-Fu, Chao Tzu-Chieh [et al.] // International Journal of Endocrinology. - 2013. - Vol. 2013. - 6
Висновок. Наведені вище дані про лікування спостережуваних нами хворих на рак ЩЗ свідчать про те, що у хворих на мультифокальну карциному порівняно з хворими на монофокальну карциному операційне лікування частіше проводили в 1999-2008 pр., у них частіше застосовували тиреоїдектомію з дисекцією і значно рідше - інші операції, у тому числі й кінцеву тиреоїдектомію, у цих пацієнтів частіше здійснювали повторні операції, відмічали частіше трикратне і більше застосування радіойоду, серед них реєстрували більше невилікуваних хворих, за ними здійснювали триваліше спостереження після операції.

p. [Електронний ресурс]. - Режим доступу: 01.02.2016 http:// www.hindawi.com/iournals/ije/2013/64.

6. Gemsenjager E. W. Multifocal papillary thyroid carcinoma / E. W. Gemsenjager, Heiz, L. Schweizer // New England Journal of Medicine. - 2005. - Vol. 353. - P. 1067-1068.

7. Ricci J. A. Multifocal Micropapillary Thyroid Cancer: a New Indication for Total Thyroidectomy? / J. A. Ricci, A. E. Alfonso // The Amarican Surgeon. - 2012. - Vol. 78. - № 11. - P. 12111214.

8. Well differentiated thyroid cancer: Long-term follow-up of thyroid cancer // Endocrine Surgery [Електронний ресурс]. - Режим доступу: http://cornellsurgery.org/pro/services/endocrine/ thyroid-follow-up.html

9. Pearce E. Pappilary thyroid carcinoma outcomes and implications for treatment/ Elizabeth Pearce, Lewis Braveman// The Journal of Clinical Endocrinology and Metabolism. - 2004. Vol. 9 - Issue 8 [Електронний ресурс].- http://press.endocrine. org/doi/full/10.2010/jc.2004-1189. 
10. Multifocality in well-differentiated thyroid carcinomas calls for total thyroidectomy/ H. M. Mazeh, Y. Samet, D. Hochstein [et al.] // The American Journal of Surgery. - 2011. - Vol.201. № 6. - P. 770-775.

11. Prophylactic central neck dissection for papillary thyroid cancer / M. Barczynski, A. Konturek, M. Stopa, W. Nowak // British Journal of Surgery. - 2013. - Vol. 100. № 3. - P. 410-418. 12. Complications of central neck dissection in patients with papillary thyroid carcinoma: results of a study on 1087 patients and review of the literature / D. Giordano, R. Valcavi, G. B. Thompson [et al.] // Thyroid.- 2012. - Vol. 22. - № 9. P. 911-917.

13. Мультифокальная папиллярная тиреоидная карцинома. Консенсус Європейского общества эндокринных хирургов (Work shop "Surgery of Thyroid Cancer”, ESES, Berlin, Germani, May 23-25, 2013) : обзор литературы и собственные данные / А. Е. Коваленко, М. Ю. Болгов, П. П. Зиныч, Н. Я. Кобринская // Ендокринологія. - Т. 20, № 4. - С. 721-734.
14. Clinical characteristics and surgical resection of multifocal papillary thyroid carcinoma: 168 cases / Guomin Huang, Xiaofeng Tian, Yuhui Li, Fujian Ji // Iternational Journal of Clinical Exposure Medicine. - 2014. - Vol.7. - No 12. - pp.58025807 [Електронний ресурс]. - Режим доступу: http://www.ijcem.com/files/ijcem0002776.pdf

15. Multifocal pappilary thyroid carcinoma - a consensus report of the European Society of Endocrine Surgeons (ESES): Review Article / M. Iacobone, S. Jansson, M. Barczynskyi, P. Goretzki // Langenbeck's Archives of Surgery. - 2014. - Vol. 399. - P.141-154.

16. Should all papillary thyroid microcarcinomas be aggressively treated?: an analysis of 18,445 cases / X.- M. Yu, Y. Wan, R. S. Sippel, H. Chen // Annals of Surgery. - 2011. - Vol. 254.№ 4.- P. 653-660.

17. Multifocal Papillary Thyroid Cancer Increases the Risk of Central Lymph Node Metastasis / Al Afif Ayham, A. Williams Blair, Rigby Mathew [et al.] // Thyroid. - 2015. - Vol. 25(9). P. 1008-1012. 